\title{
Effect of Date of Sowing on Productivity of Black Cumin
}

\author{
Samima Sultana ${ }^{1}$, Bhabani Das ${ }^{1}$, Bankim Chandra Rudra ${ }^{1}$, \\ Ganesh Das $^{2 *}$ and Md Banaz Alam ${ }^{3}$ \\ ${ }^{1}$ Horticulture, Malda Krishi Vigyan Kendra, Uttar Banga Krishi Viswavidyalaya, Ratua, \\ Malda, West Bengal, India \\ ${ }^{2}$ Agriculture extension, Coochbehar Krishi Vigyan Kendra, Uttar Banga Krishi \\ Viswavidyalaya, India \\ ${ }^{3}$ Jalpaiuri Krishi Vigyan Kendra, WBUFAS, India \\ *Corresponding author
}

\begin{abstract}
A B S T R A C T
Keywords

Black cumin, Date of sowing, Nigella,

Spices plant, Sowing time

Article Info

Accepted:

14 December 2017

Available Online:

10 January 2018

The experiment was carried out during rabi season during 2016-2017 at Malda District of West Bengal ascertain the best sowing date to get high yield and quality in nigella. The study consisted of four different sowing dates like T1 -Cultivation of Black Cumin in mid-September, T2Cultivation of Black Cumin in end of September, T3 -Cultivation of Black Cumin in mid. October, T4-Cultivation of Black Cumin in early November, T5: Farmers practice (October- November). The different dates of sowing had significant influence on the morphological, growth, yield and quality attributes of the crop.
\end{abstract}

\section{Introduction}

Nigella (Nigella sativa L.) is a spice crop that belongs to Ranunculaceae, the butter cup family. The seeds or grains resembling onion seed, are used both as spice and medicine.

The crop is known by many common names viz. black-caraway, black-cumin, fennelflower, nigella, nutmeg-flower and romancoriander. It is believed to have originated in the Mediterranean region and subsequently spread to Europe, Asia and Africa. Seeds of this plant were used both as spice and medicine since a very long time. The seeds are bitter in taste and consumption of whole seed even in small quantity gives a feeling of constriction of throat. It is appropriately known as seed of blessing (habbatul barakah) (Srivastava, 2014). The spice was attributed with numerous medicinal properties and is widely used in unani, ayurveda, siddha and other ethnomedicine systems across the world (Padmaa, 2010). The medicinal value of the spice is immense and numerous workers appreciated its unique, varied and powerful 
pharmacological traits. The popularity of the plant was highly enhanced by the ideological belief in the herb as a cure for multiple diseases. likes anti-tumour anti-diabetic, cardioprotective, gastroprotective), antiasthmatic, nephroprotective, hepatoprotective, antiinflmmatory, immunomodulatory, neuroprotective, anticonvulsant, anxiolytic, antioxidant, antinociceptive, antioxytocic, contraceptive, antibacterial antifungal, and anthelmintic activities were immensely appreciated. The major medicinal components are thymoquinone and nigellone (a dimer of thymoquinone). These were attributed to impart anti-tumour, antiinflammatory and anti-diabetic properties (Woo et al., 2012).

The crop is presently cultivated in parts of Asia, Africa, Europe and Americas of the globe. The major producing countries are India, Sri Lanka, Bangladesh, Afghanistan, Pakistan, Egypt, Iran, Iraq, Syria, Turkey and Ethiopia. In India, it is grown in many parts, particularly in Madhya Pradesh, Bihar, Punjab, Assam, Jammu and Kashmir, Himachal Pradesh, Uttar Pradesh, Rajasthan, West Bengal and Tamil Nadu. Among the countries that export black cumin, the major ones are India, Syria, Ethiopia and Turkey. The major seed spices grown in West Bengal are coriander, fenugreek, cumin, black cumin and Fennel.

Nigella though found suitable as rabi crop for West Bengal, there is lack of information on agro-management practices due to weather variation. So Proper time of seed sowing and improve crop management are the crucial in the success of the crop. Further, optimal crop stand and its interaction with season influences yield attributes and yield. So keeping all the point in mind, an experiment was carried out that the effect of sowing time on growth, yield and quality of black cumin in Malda district of West Bengal.

\section{Materials and Methods}

The experiment was conducted in farmer's field of Malda district, West Bengal, India, during the year 2016-17 with high yielding black cumin variety). Geographically, experimental site situated at $23.5^{\circ}$ North latitude, $89^{\circ}$ East longitude having an average altitude of $9.75 \mathrm{~m}$ above mean sea level. The experimental site was located in sub-tropical humid climate with gangetic old alluvial soil, sandy clay loam texture, good water holding capacity, well drained, and with acidic to neutral reaction and moderate fertility status. The experiment Design was randomized block design (RBD) with four (5) treatments and seven (7) replications.

The treatments were: T1 -Cultivation of Black Cumin in mid-September, T 2- Cultivation of Black Cumin in end of September, T3Cultivation of Black Cumin in mid. October, T4-Cultivation of Black Cumin in early November, T5: Farmers practice (OctoberNovember)

The experiment land was plowed, cultivated and then prepared for seed sowing through broadcasting method. For the experiment on different dates of sowing well rotten farm yard manure was applied as a basal dose at the rate of 20 quintal per hectare.

The crop was fertilized with nitrogen, phosphorus and potassium @ 40-20-20 kg ha-1 in the form of urea, single super phosphate and muriate of potash, respectively. Two days prior to sowing, half the dose of $\mathrm{N}$ and full dose of phosphorus and potassium were applied as basal application and was properly mixed with the soil. Remaining half dose of nitrogen was applied as top dressing at 30 days after sowing (DAS). Seeds were start sown by hand in third week of September in the ratio of $15 \mathrm{~kg} \mathrm{ha}^{-1}$. The distance between rows was $20 \mathrm{~cm}$ and within the rows were 5 
$\mathrm{cm}$. Seeds were sowed at 1-2 $\mathrm{cm}$ depths soil. The crop was irrigated immediately after sowing for obtaining better and uniform germination. Subsequently the irrigations were given at 10 days interval depending upon the moisture condition of the experimental plot to maintain uniform soil moisture throughout the crop growth period. Immediately after the germination of the seeds, gap filling was taken up to maintain uniform plant population.

First thinning was taken up to maintain optimum plant population at 15 DAS and second thinning was taken up 10 days after the first thinning. The experimental plot was kept weed free throughout the crop growth period with supplementary hand weeding and plant protection was taken time to time. The crop was harvested at maturity when the capsules turned to brown colour and dried. Harvesting was done by pulling the plants. The border rows from each plot were harvested first leaving the net plot area. Later, net plot area was harvested after separating the plants designated for recording biometrical observations. The harvested plants were sundried for three days and threshing was done by beating with sticks. The seed was winnowed and cleaned subsequently for recording yield data

\section{Observations on the crop}

Plant height was recorded from the ground level to the tip of the last leaf or flower at 30, 60, 90 days after sowing and at harvest. Average plant height was then expressed in $\mathrm{cm}$. The branches from five randomly selected plants from each plot were counted at 30,60, 90 DAS and at harvest. The average was computed and expressed as number of branches per plant. The capsules harvested from plants were threshed, winnowed carefully. The seed lots thus obtained were taken and weight was recorded using electronic balance.

\section{Results and Discussion}

\section{Physical parameters}

\section{Plant growth}

Hafez (1998) reported that the growth parameter like plant height, basal and lateral branches per plant, fresh weight of the plant were pronouncedly increased when black cumin seeds are sown during October month. Plant height was found maximum with midweek of October sown crops $(32.12 \mathrm{~cm})$ and similarly the same date was found superior in producing maximum number of leaf.

In case of dates of sowing, the maximum number of branches was recorded on midOctober sown crop (3 and 4 branches respectively). Datta et al., (2008) also found an increase in plant height in black cumin with the advancement of sowing time upto 15th November and thereafter it decreased gradually.

He also found increasing trend in number of primary and secondary branches per plant in at early sown plants in black cumin. Gowda et al., (2006) had recorded a similar kind of observation in fenugreek in relation with date of sowing (Table 1).

\section{Yield parameters}

Among the yield and yield attributing parameters shows highest yield on midOctober sowing crop (3.65 quintal/ hectare). Malhotra and Vashishtha (2008) reported that sowing during second fortnight of October was suitable for optimum growth and yield of nigella. Majumder et al., (2012) studied the crop response to six dates of sowing and two spacings in Gangetic plains of West Bengal. They reported that sowing dates and spacings have significant effect on number of pods per plant, number of seeds per pod and seed yield. 
Table.1 Physical and yield attributing parameters

\begin{tabular}{|l|c|c|c|}
\hline Treatments & Plant height $(\mathbf{c m})$ & Branch no & Yield(quintal/hectare) \\
\hline T1 & $\mathbf{2 1 . 0 7}$ & $\mathbf{2 . 9}$ & $1.98 \mathrm{q} / \mathrm{ha}$ \\
\hline T2 & $\mathbf{2 4 . 3 7}$ & $\mathbf{3 . 1}$ & $2.40 \mathrm{q} / \mathrm{ha}$ \\
\hline T3 & $\mathbf{3 2 . 1 2}$ & $\mathbf{4 . 8}$ & $\mathbf{3 . 6 5}$ q/ha \\
\hline T4 & $\mathbf{2 7 . 2 4}$ & $\mathbf{3 . 8}$ & $3.05 \mathrm{q} / \mathrm{ha}$ \\
\hline T5 & $\mathbf{2 5 . 6 9}$ & $\mathbf{3 . 2}$ & $2.10 \mathrm{qq} / \mathrm{ha}$ \\
\hline
\end{tabular}

Table.2 Economic analysis

\begin{tabular}{|l|l|l|l|l|}
\hline Treatments & $\begin{array}{l}\text { Cost of cultivation } \\
\text { (Rs./ha) }\end{array}$ & $\begin{array}{l}\text { Gross return } \\
\text { (Rs/ha) @ 300/kg }\end{array}$ & $\begin{array}{l}\text { Net return } \\
\text { (Rs./ha) }\end{array}$ & BC ratio \\
\hline T1 & 55600 & 59400 & 3800 & 0.68 \\
\hline T2 & 55600 & 72000 & 16400 & 1.29 \\
\hline T3 & $\mathbf{5 5 6 0 0}$ & $\mathbf{1 0 9 5 0 0}$ & $\mathbf{5 3 9 0 0}$ & $\mathbf{1 . 9 6}$ \\
\hline T4 & 55600 & 915000 & 35900 & 1.64 \\
\hline T5 & 55600 & 63000 & 7400 & 1.13 \\
\hline
\end{tabular}

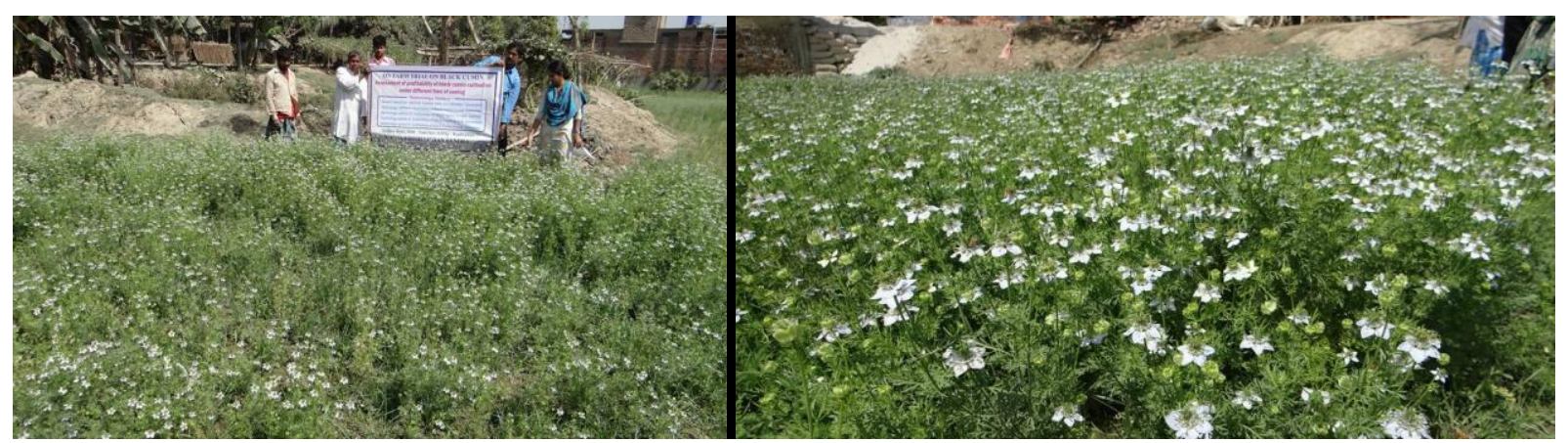

Meena et al., (2011 and 2012) conducted a two year study during 2002-2004 to find out the response of nigella cv. AN-1 to combined effect of crop geometry and time of sowing under semi-arid conditions. They reported that highest yield among different dates of sowing was obtained with sowing on $15^{\text {th }}$ October with a row spacing of $25 \mathrm{~cm}$.

The economic assessment for the treatments was done on the basis of cost of cultivation, gross and net return, considering the cost of inputs and market price of the produce during the period of experimentation (Table 2).
It can be concluded that performance from the date of sowing of black cumin it may be concluded that the black cumin sown during mid-October recorded highest yield of 3.65 $\mathrm{q} / \mathrm{ha}$ and the crop sown during early November recorded $3.05 \mathrm{q} / \mathrm{ha}$, which are higher than the crop sown during the month of September (2.40 q/ha). The yield of Black Cumin sown in mid-October (B: $C$ ratio 1.96) and sown during early Nov. (B: C ratio 1.64) are $73.8 \%$ and $45.2 \%$ higher than local check $(2.10 \mathrm{q} / \mathrm{ha})$ particularly in the old alluvial zone of West Bengal. 


\section{References}

Dutta, D., Bandyopadhyay, P. and Maiti, D. 2008. Effect of $\mathrm{P}$ fertilization and growth regulators on yield, nutrient uptake and economics of fenugreek (Trigonella foenum graecum L.). Research on Crops. 9(3): 599-601.

Gowda, M. C., Halesh, D. P. and Farooqi, A. A. 2006. Effect of dates of sowing and spacing on growth of fenugreek (Trigonella foenum-graecum L.). Biomed. 1(2): 141-146.

Srivastava, B. 2014. Medicinal and therapeutical potential of Nigella sativa. International journal of medical and applied sciences research. 1 (1): 32- 39.

Malhotra, S.K. and Vashishtha, B.B. 2008. Response of nigella (Nigella sativa $\mathrm{L}$ ) variety NRCSS AN 1 to different agrotechniques. Journal of Spices and Aromatic Crops. 17(2): 190-193.

Majumder, C., Pariari, A., Khan, S. and Singh, L.S. 2012. Determination of optimum date of sowing of black cumin (Nigella sativa L.) for gangetic alluvial plains of West Bengal. In Proceedings of State level seminar on Production \& Management of spices in West Bengal. Held during 1-2nd March, 2012 at Bidhan Chandra Krishi Viswavidyalaya,
Kalyani. https://sites.google.com/site /bckvspices/home/abs20121/abstract-16 [Accessed on 17-07-2014].

Meena, S.S., Anwer, M.M., Mehta, R.S., Lal, G., Kant, K., Sharma, Y.K., Vishal, M.K., Jingar, K.L. and Meena, S.R. 2011. Performance of nigella (Nigella sativa $\mathrm{L}$.) as influenced by sowing dates and crop geometry in semi-arid ecosystem. International Journal of Seed Spices. 1 (1): 8-12.

Meena, S.S., Mehta, R.S., Lal, G., Kant, K., Sharma, Y.K., Saxena, S.N. and Anwer, M.M. 2012. Essential oil, fatty oil and seed yield of nigella (Nigella sativa L.) as influenced by sowing dates and crop geometry. Indian Journal of Horticulture. 69 (4): 591-593.

Hafez, M.H. 1998. Effect of plant density, planting date, nitrogen fertilization sources and some nutrients on growth, flowering, seed yield and oil yield of Nigella sativa L. Plants. Ph.D. Thesis. Minia University, Minya, Egypt.

MELHassan, A. 2017. Technological Factors Affecting Adoption of Zero Tillage Farming by Agadi Households FarmersBlue Nile State- Sudan. Agricultural Extension Journal (AEXTJ), 1(5).

\section{How to cite this article:}

Samima Sultana, Bhabani Das, Bankim Chandra Rudra, Ganesh Das and Md Banaz Alam. 2018. Effect of Date of Sowing on Productivity of Black Cumin. Int.J.Curr.Microbiol.App.Sci. 7(01): 1796-1800. doi: https://doi.org/10.20546/ijcmas.2018.701.217 